\title{
PENGARUH PROSES PENGOLAHAN TERHADAP KADAR LOGAM BERAT DAN KADAR GIZI PADA KACANG PANJANG
}

\author{
Hening Widowati ${ }^{1}$ \\ Widya Sartika Sulistiani² \\ Agus Sutanto ${ }^{3}$ \\ ${ }^{1,23)}$ Pendi dikan Biol ogi FKIP Uni versitas Muhammadiyah Metro \\ E-mail:hwummetro@gmail.com, widya.sulistiani@gmail.com, sutanto11@gmail.com
}

\begin{abstract}
The nutritional quality of yardlong beans is determined from the environment in which the food is grown. The contaminated environmental conditions will affect the nutritional quality of yardlong beans. Food processing before consumption is expected to reduce the impact of heavy metal accumulation on yardlong beans. The purpose of this study was to find out the appropriate method of food processing to reduce heavy metal content but still maintain the nutritional value of yardlong beans which is grown in potentially polluted environments. The research method was experiment with processed the yardlong beans that have been washed 3 times by steaming (BW3), boiled (CW3) and pan-fried (DW3) compared to washed food 3 times without being processed (AW3). Based on the results of the research that steaming method is the best method because it can reduce the heavy metal content but can still maintain the levels of vitamin A, protein and vitamin $C$ in yardlong beans.
\end{abstract}

Kata kunci: pengolahan makanan, logam berat, kualitas gizi, kacang panjang.

Sayuran yang ditanam pada lingkungan yang baik akan menghasilkan kualitas gizi yang baik pula bagi konsumen yang memanfaatkannya. Akan tetapi kondisi lingkungan yang baik ini semakin jarang ditemui. Kondisi kualitas lingkungan saat ini terus mengalami penurunan menyebabkan semakin jarangnya daerah bebas dari kontaminasi bahan pencemar yang dapat dimanfaatkan masyarakat untuk menanam tanaman pangan. Bahan pencemar seperti logam berat pada media tanam dapat terserap bersama nutrisi yang diperlukan oleh tanaman pangan untuk tumbuh, sehingga berakibat pada penurunan kadar gizi pada tanaman pangan tersebut (Widowati et al. 2016). Logam berat yang terdapat pada tanaman pangan juga dapat terakumulasi dalam tubuh manusia jika dikonsumsi terus menerus.

Biasanya, sayuran seperti kacang panjang sering dikonsumsi oleh masyarakat tanpa melalui proses pengolahan, yaitu dalam bentuk lalapan, maupun setelah melalui proses pemasakan seperti perebusan, pengukusan dan penumisan. Pengolahan bahan makanan yang baik dapat menurunkan kadar logam berat pada bahan pangan sebelum dikonsumsi. Pengolahan bahan pangan juga akan berdampak pada kadar gizi dari bahan pangan tersebut. Menurut Ramadhan dan Aminah (2014), proses dan metode pemasakan menyebabkan perubahan signifikan dalam komposisi kimia sayuran dan mempengaruhi senyawa bioaktifnya baik dengan cara positif (meningkatkan kandungannya) 
ataupun negatif (menurunkan kandungannya). Proses pemasakan yang baik dengan cara perebusan maupun pengukusan dapat menurunkan kadar asam sianida yang terdapat pada rebung bambu (Putra, 2009).

Pengaruh penurunan kadar gizi bahan makanan setelah pengolahan akan berbeda-beda tergantung pada jenis bahan pangannya serta suhu yang digunakan pada saat pengolahan (Sundari dkk, 2015). Pada penelitian ini tanaman kacang panjang digunakan sebagai objek pengamatan, khususnya pada daun dan buah kacang panjang. Tujuan dari penelitian ini adalah untuk menganalisis pengaruh pengolahan daun dan buah kacang panjang terhadap kadar logam berat dan kadar gizinya. Variasi metode pengolahan yang diamati adalah pengolahan dengan pengukusan, perebusan, dan penumisan. Logam berat yang dianalisis adalah timbal $\mathrm{Pb})$ dan kadmium (Cd), sedangkan zat gizi yang dianalisis adalah Vitamin A, Protein dan Vitamin C.

\section{METODE}

\section{Alat dan Bahan}

Peralatan yang dibutuhkan dalam penelitian ini adalah alat gelas dan spektrofotometer visible. Bahan yang digunakan dalam penelitian ini adalah tanaman kacang panjang dari petani yang telah lama menggunakan pertisida buatan kemudian diambil sampel daun dan buah kacang panjangnya

\section{Metode eksperimen}

Sampel daun dan buah kacang panjang yang digunakan dalam eksperimen ini dipanen langsung dari lahan petani. Sebelum diolah, sampel dicuci dengan air bersih sebanyak 3 kali. Setelah itu sampel tersebut langsung diolah dengan dikukus (BW3), direbus (CW3) dan ditumis (D). Ketiga metode pengolahan tersebut kemudian dibandingkan dengan sampel tanpa pengolahan (AW3). Sampel tersebut kemudian dianalisis kadar logam berat dan kadar gizinya di Laboratorium Universitas Muhammadiyah Malang. Logam berat yang dianalisis pada penelitian ini adalah timbal $(\mathrm{Pb})$ dan kadmium $(\mathrm{Cd})$ dengan menggunakan metode spektrofotometri. Sedangkan zat gizi yang dianalisis adalah vitamin $\mathrm{C}$ dengan metode titrimetri, protein dengan metode semi mikro kjeldahl, dan vitamin A dengan metode spektrofotometri. Untuk mengawetkan bahan pangan yang akan dianalisis tersebut maka ditambahkan sedikit pengawet asam benzoat.

\section{HASIL}

Hasil analisis kadar logam berat $\mathrm{Pb}$ dan $\mathrm{Cd}$ serta kadar gizi daun dan buah kacang panjang yang telah diolah dengan dikukus (BW3), direbus (CW3) dan ditumis (DW3) dibandingkan dengan kadar gizi kacang panjang tanpa pengolahan (AW3) 
Tabel 1. Kadar logam berat dan kadar gizi daun kacang panjang terhadap proses pengolahan : Tanpa pengolahan (AW3), Pengukusan (BW3), Perebusan (CW3) dan Penumisan (DW3)

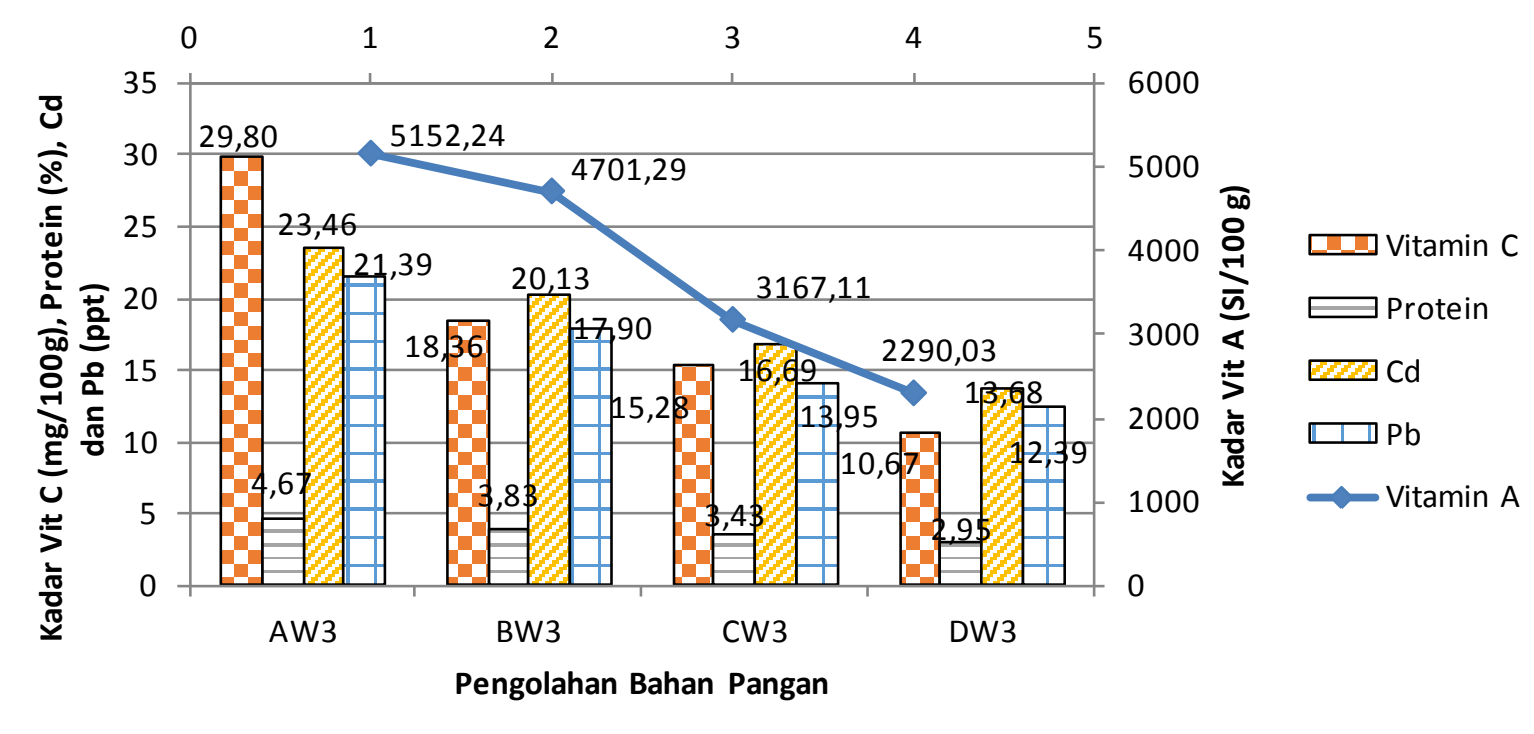

Tabe12. Kadar logam berat dan kadar gizi buah kacang panjang terhadap proses pengolahan : Tanpa pengolahan (AW3), Pengukusan (BW3), Perebusan (CW3) dan Penumisan (DW3)

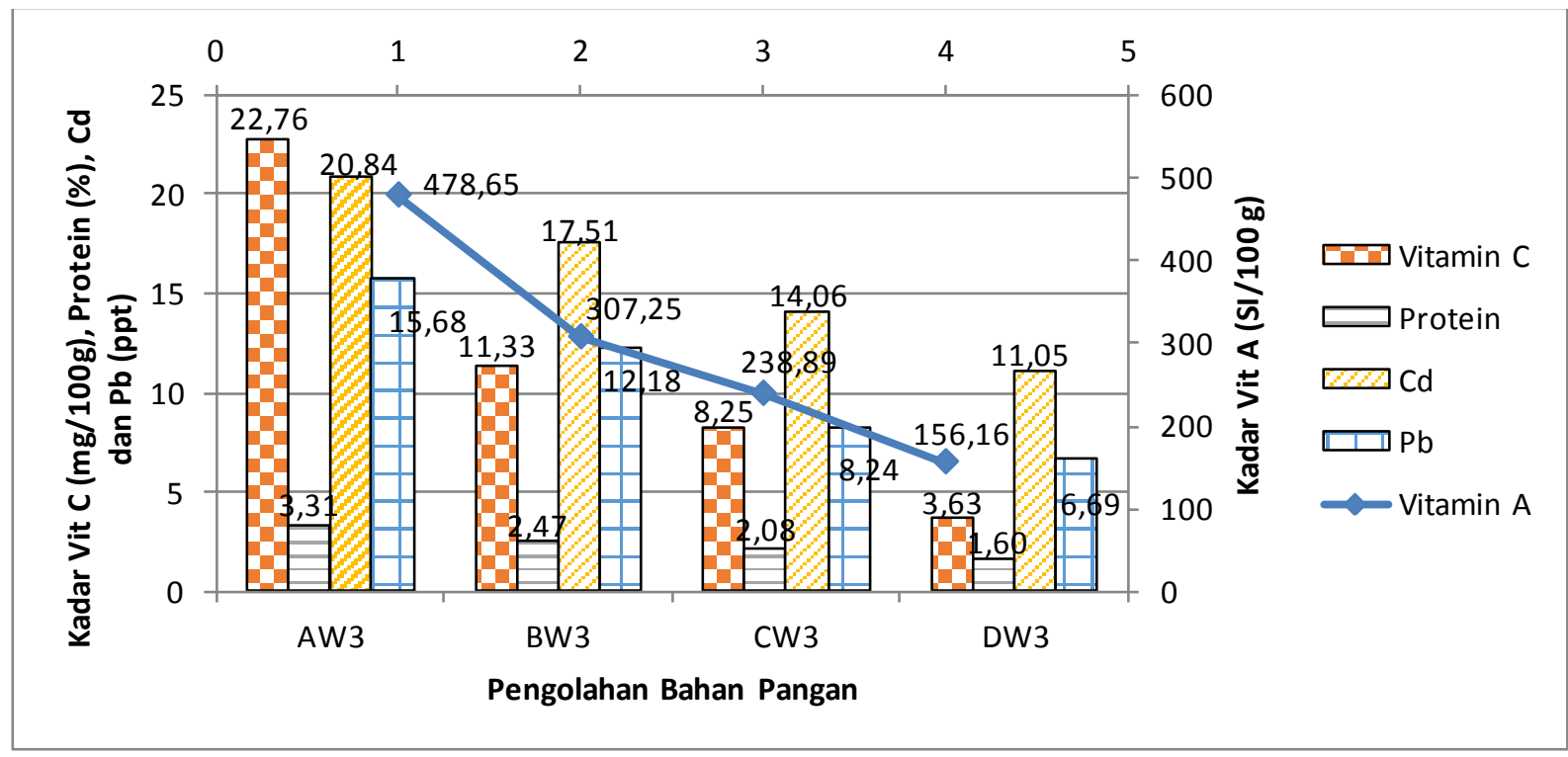

Berdasarkan Tabel 1 dapat diketahui bahwa proses pengolahan berpengaruh terhadap penuruanan kadar vitamin C, Vitamin A dan Protein pada daun kacang panjang. Persentase penurunan kadar vitamin A daun kacang panjang setelah dikukus $(8,75 \%)$ lebih rendah dengan persentase penurunan kadarnya setelah direbus $(38,53 \%)$ maupun ditumis $(55,5 \%)$. Hal ini bisa diartikan bahwa daun kacang panjang yang diolah dengan cara direbus dan ditumis dapat merusak kandungan vitamin A pada daun kacang panjang. Selain kadar vitamin A, kadar vitamin 
C dan protein setelah pengolahan dengan dikukus, direbus dan ditumis juga mengalami penurunan.

Pengolahan dengan dikukus, direbus dan ditumis juga dapat menurunkan kadar logam berat $\mathrm{Pb}$ dan $\mathrm{Cd}$. Kadar $\mathrm{Pb}$ setelah pengukusan, perebusan dan penumisan berkisar antara 20,13 13,68 ppt. Berdasarkan Standar Nasional Indonesia (SNI) tentang batas maksimum cemaran logam berat $\mathrm{Pb}$ dan $\mathrm{Cd}$ dalam pangan khususnya buah dan sayur adalah 0,2 $\mathrm{mg} / \mathrm{kg}$ atau $0,2 \mathrm{ppm}$. Kadar $\mathrm{Pb}$ dan $\mathrm{Cd}$ sebelum dan sesudah pengolahan daun kacang panjang pada penelitian ini berdasarkan SNI masih tergolong aman untuk dikonsumsi.

Sama halnya dengan hasil analisis kadar gizi dan kadar logam berat daun kacang panjang, kadar gizi dan kadar logam berrat pada buah kacang panjang juga mengalami penurunan. Metode pengolahan paling baik berdasarkan Tabel 2 adalah dengan metode pengukusan (BW3). Hal ini desebabkan karena pengolahan buah kacang panjang dengan pengukusan dapat menurunkan kadar logam berat tetapi dapat tetap mempertahankan kadar gizi pada buah kacang panjang. Kadar logam $\mathrm{Pb}$ dan $\mathrm{Cd}$ pada buah kacang panjang masih berada pada batas aman untuk dikonsumsi berdasarkan Standar Nasional Indonesia.

\section{PEMBAHASAN}

Kacang panjang merupakan salah satu tanaman sayur yang banyak ditanam oleh masyarakat Indonesia terutama di daerah dataran rendah. Kandungan protein dalam kacang panjang cukup tinggi sehingga dapat menjadi sumber protein nabati. Kadar protein pada biji kacang panjang kering sebesar 22,3\%, pada daun kacang panjang sebesar 4,1 \% dan $2,7 \%$ pada polong muda kacang panjang. Selain protein kacang panjang juga mengandung tiamin, riboflavin, vitamin $\mathrm{A}$, asam askorbat, asam folat dan beberapa mineral lainnya (Kaswinarni dkk, 2014). Hal ii berbeda dengan hasil analisis kadar protein pada daun kacang panjang tanpa pengolahan yaitu $4,67 \%$ sedangkan pada buah kacang panjang sebesar 3,31\%. Kadar protein daun kacang panjang pada penelitian ini lebih tinggi dibandingkan dengan kadar protein pada buah kacang panjang.

Besarnya kandungan gizi pada kacang panjang sangat bermanfaat jika dikonsumsi oleh manusia. Akan tetapi kondisi lingkungan tempat kacang panjang tersebut hidup perlu diperhatikan. Hal ini disebabkan karena tanaman kacang panjang memperoleh nutrisi dari lingkungan tempat dia tumbuh. Bahan pencemar yang mencemari lingkungan tersebut dapat terserap bersama nutrisi yang masuk melalui akar dan terakumulasi pada bagian-bagian tanaman kacang panjang.

Pengolahan bahan pangan sebelum dikonsumsi sangat penting untuk mengurangi kadar logam berat pada bahan pangan. Berdasarkan hasil penelitian, dapat diketahui bahwa pengolahan dengan metode pengukusan, perebusan dan penumisan dapat menurunkan kadar logam berat $\mathrm{Pb}$ dan $\mathrm{Cd}$ pada daun dan buah kacang panjang. Akan tetapi bukan hanya kadar logam berat saja yang berkurang, kadar gizi seperti vitamin $\mathrm{A}$, protein dan vitamin $\mathrm{C}$ daun dan buah kacang panjang juga mengalami penurunan setelah pengolahan.

Berdasarkan hasil pengamatan ketiga variasi pengolahan maka 
pengolahan dengan pengukusan merupakan metode yang paling baik karena dapat menurunkan kadar logam berat akan tetapi dapat tetap mempertahankan kadar vitamin A, protein dan vitamin $\mathrm{C}$ pada bahan pangan. Pada proses pengukusan, zat gizi bahan pangan yang diolah tidak banyak yang hilang karena tidak menggunakan media lain pada prosesnya. Sedangkan pada metode perebusan bagi logam berat maupun zat gizi juga banyak yang hilang karena terlarut dalam air rebusan. Proses penumisan menyebabkan penurunan logam berat dan kadar gizi yang paling besar karena pada prosesnya menggunakan suhu yang tinggi sehingga zat gizi seperti vitamin $A$, protein dan vitamin $C$ yang sensitif terhadap suhu juga mengalami kerusakan. Hasil penelitian ini juga terjadi pada penelitian Sundari dkk (2015) yang mengamati pengaruh proses pemasakan terhadap komposisi zat gizi bahan pangan sumber protein seperti daging ayam segar, ikan kembung segar, tempe dan tahu.

Walaupun pengolahan bahan pangan dapat menurunkan kadar gizi pada bahan pangan, akan tetapi pengolahan tetap diperlukan agar bahan pangan yang dikonsumsi tersebut aman dari logam berat atau bahan pencemar lainnya seperti mikroorganisme patogen. Pengolahan bahan pangan juga dapat meningkatkan daya cerna bahan pangan dan cita rasa bahan pangan.

\section{KESIMPULAN}

Berdasarkan hasil dan
pembahasan di atas dapat
disimpulkan bahwa metode
pengolahan yang tepat untuk daun

dan buah kacang panjang adalah metode pengukusan. Metode pengukusan dapat menurunkan kadar logam berat $\mathrm{Pb}$ dan $\mathrm{Cd}$ pada daun dan buah kacang panjang tetapi kadar gizinya masih cukup baik dipertahankan.

\section{DAFTAR RUJUKAN}

Badan Standardisasi Nasional. 2009. Batas Maksimum Cemaran Logam Berat dalam Pangan. SNI 7387:2009

Kaswinarni, F., B. Suharno, W. Hendro dan O. A. Winarta. 2014. Berbagai Fenomena Kacang Panjang (Vigna sinensis) terhadap Penambahan Kompos Organik Pada Pemupukan Batuan Fosfat. Bioma Volume 3 Nomor 1.

Putra, I N K. 2009. Efektifitas Berbagai Cara Pemasakan Terhadap Penurunan Kandungan Asam Sianida Berbagai Jenis Rebung Bambu. Agrotekno Volume 15 Nomor 2: 40-42

Ramadhan, T dan S. Aminah. 2014. Pengaruh Pemasakan Terhadap Kandungan Antioksidan Sayuran. Buletin Pertanian Perkotaan Volume 4 Nomor 2.

Sundari, D., Alamsyhuri., A. Lamid. 2015. Pengaruh Proses Pemasakan terhadap Komposisi Zat Gizi Bahan Pangan Sumber Protein. Media Litbangkes. Vol. 25 No 4, 235-242

Widowati, H.; K. Sari; dan W. S. Sulistiani. 2016. The management of vegetable cultivation to protect the consumer from heavy metal pollution. Scientific Journal of PPI-UKM 3(4): 2356-2536. 